\title{
THE STRUGGLE OF WOMEN EXISTENCE IN “ISN'T IT ROMANTIC" NOVEL BY WENDY WESSERSTEIN
}

\author{
Devi Cintia Kasimbara \\ Universitas PGRI Madiun, East Java, Indonesia \\ devi.ck@unipma.ac.id
}

\begin{abstract}
This study aimed to reveal the struggle of women to gain existence in the novel as a representation of social phenomena. The data source of this research was Isn't It Romantic drama by Wendy Wesserstein. This drama is about women who want to achieve their dreams without the participation of their parents. They want to live without any interference from their parents. To reveal the struggle for existence, the researcher uses the existentialism approach by Simone Beauvoir. Existentialists fight for the nature of human existence, especially for women who have been subordinated to the patriarchal system. The method used in this research is Descriptive qualitative method. The close reading data collection method is effective in tracing data relevant to research variables. The analysis method is carried out critically by using an existentialism approach. The researcher got three main analyses toward the novel, they are: independence over women, authority in making decisions, and lastly, the same existence as a human being.
\end{abstract}

Keywords: The Struggle of Woman, Existentialism, Patriarchal Domination, Woman self-independency

\section{INTRODUCTION}

The phenomenon was found in the website news namely The Times. It was posted by the author David Aaronovitch. There was a women who exists her existence in her life. The women's name Helen Joyce, she stated that "most people thought, and many still do, that trances mean 'trans sexuality': such a deep discomfort with one's sexed". From the phenomenon above it was identified as a existence of women, which described how women can exist in the world even though they are transgender. Then, there is no one blocking them to make activity as another people. This phenomenon was related with this research about the existence of women.

Literature is an art form that is conveyed in the form of short story, poetry, and drama in which there are emotions and ideas from someone who cares about life. Literary works were immensely popular a long time ago, literary work were developed was represented and had meaning from the 


\section{s Science ftumanity Pournal}

author or writer of the literary work and had a special aim for the responsiveness of an artistic expression. Work on the novel is currently moving at a breakneck pace. A study of literature is required to analyze a literary work, and this science has existed since of yore. A study of literature is required to analyze a literary work, and this science has existed since past times. To further clarify the previous statement, it is discovered that there are various classic dramas that have another genres, such as "Isn't It Romantic" dramas. The genre of this drama is comedy

In this research, researchers are very anxious to investigate the existence of women. Sakinah (2014) claimed that women's images are infused into literary works through characters who feature frequently. Researcher was interested to analyze the drama "Isn't It Romantic" by Wendy Wasserstein as a data source. This research takes a feminist approach in this literary work by Showalter (1997), because this theory based on the women's image theory.

There are many studies that are quiet inspiring in the development of this research idea. One of them was written by Simanungkalit \& Putra (2020) examined the image of women in Little Women's novel by Louisa May Alcott. This research was applied the theory by Showalter (1997). The data source was collected from novel Little Women's by Louisa May Alcott. The result of this research was women cannot be separated from the issues surrounding women who experience complicated life.
The second writter was discussed about the image of women also. It was delivered by Pruis \& Janowsky (2010). Janowsky investigated the body image of women. The researcher use theory of feminisme approach. This research was found women's responses to fatter and thinner images of their own bodies versus responses to line drawings of bodies in the Figure Ratings Scale were compared in younger versus older women using questionnaires and women's responses to fatter and thinner images of their own bodies versus responses to line drawings of bodies.

The third article is discussed by Sinta , S., \& Ambalegin, A. (2020) yang membahas tentang upaya perempuan untuk melawan dominasi patriakal didalam drama Romeo dan Juiet. The results of this study indicated that women at that time were only seen as objects in patriarchal societies which placed the position of men, especially fathers as leaders and decision makers. Last, Feminist Representation in Poe's To Helen is examined by F. Kuhon (2020). Poe, he claims, depicted women in a way that was diametrically opposed to his main topic of beautiful oppressed ladies. The woman was depicted in this poetry as fair, compassionate, consoling, and wise to the point where a person felt love and home with her.

The contrast of this research to discovered the existence of women in image of women in this research. This research is very important because the women's image in society is very significant. The reason is that there is still much discrimination received by women after marriage and also in personal relationships. Discrimination is 


\section{sScience Htumanity Pournal}

not only physically accepted but also freedom of self-power in making decisions and getting the same existence as a human. Therefore, the researcher raised the title of existence of women in "Isn't It Romantic" drama by Wemdy Wesserstein

\section{LITERATURE REVIEW}

\subsection{Feminist approach}

Feminism is a social movement and set of ideals aimed at achieving gender and social equality. Feminists are critical of the growth of new ideas or opinions on women's rights as a result of technical advancements. Because of gender rights, feminist criticality is a contradiction in women. Kindersley (2019) explained that feminism is women have begun speaking out about the gender disparities they experience. It is mean that women will defend themselves if they are belittled.

\subsection{Woman Existencialism}

Existence is one of the parts in women's struggle. Webster (1828) declared that existence is the state or reality of having existed, particularly capable of independent awareness, as contrasted to unknowability. So, existence is something that must be happen to women or men because from the existence they can do everything be happy.

Based on the explained earlier the researcher has on purpose criticizes existentialist feminists in philosophy. Martin (2001) explained that the existentialist concept is a flow that emphasizes on humans, where humans are seen as an existent creature, complete the human way in the world with awareness. Dagun (1990) added that there are some characteristics of existentialism that is always seeing the way humans are, existence is interpreted dynamically so that there are elements of doing and becoming. Human are seen as a wounded and unfinished reality, and based on concrete experience. So it can be concluded that existentialism views humans as something high, and their existence is always determined by themselves, only because it is man who can exist and who is aware of himself and knows how to position himself. From this paradigm then became the basis of the existentialism heroes that were originally made by John Paul Sartre so that gave birth to existentialist feminists by Simone De Beauvoir.

Feminist existentialism based on thought by Beauvoir (2016) was very important concept in fighting for human rights. Through in her famous book the second sex. She was also considered a pioneer of feminism that is more substantive than other theories. She revealed that women who are aware of their freedom will be able to actualize themselves to the fullest. Women can be intellectual, and they don't even have to worry about their biological limitations. Women refuse to be used as object even women are also able to tempt men. She adopted the anta logical language and the existentialist ethical language of John Paul Sartre. Beauvoir (2016) revealed that men are called "the self" while women are considered "the others". Thus in the patriarchal concept to be free men must subordinate women to themselves, this is called oppression of women. Women have been socialized since children to accept, wait and even depend. They were motivated to believe that there 


\section{EScience Htumanity gournal}

will be men who will come to save their lives as in fairy tales and communities. From this Beauvoir revealed that the element of women's dependence was not only sourced from the myths of society but too many factors of life in history that did not allow women to be independent.

\section{METHODOLOGY RESEARCH}

This research was a qualitative research proposed by Cresswell (2018). The object of this research was women's image in "Isn't It Romantic" Drama by Wendy Wesserstein. This research was using Document study is the information collection approach that the author employs since it allows researchers to review documents that are directly relevant to the issue that the author is researching. The technique used in this study is to explore for references or sources of information about feminism in literature, followed by reading the drama script purposed by The researcher found the women's image applied by the women characters in "Isn't It Romantic" Drama by Wendy Wesserstein. In this study, data was grabbed in the form of a feminist approach from existencialism theory by Simone Beavoir.

\section{DISCUSSION}

This novel is talking about Best friends from college, Janie Blumberg and Harriet Cornwall, are navigating their post-college "adult" lives in New York City. They're in that late twenties, perilously close to the thirties stage of life where they feel absolutely lost and behind. Janie, an aspiring writer, meets Marty, a dashing doctor who appears to be the perfect match. Except, he referred to her as "monkey" and wants her to move in with him right away. Harriet gets a terrific job at ColgatePalmolive and has a hot connection with her boss which is a little bothersome because he's married. Janie's parents, Tasha and Simon, don't help matters by showing up at her new apartment unannounced and bringing a Russian cab driver to pose as a potential suitor. Harriet's mother, on the other hand, is a wealthy executive who is adamant about her daughter's independence. Janie and Harriet are attempting to assist each other (and themselves) in locating and curating their ideal home.

Despite her Harvard education, Janie's failure to justify her lifestyle is perceived as a failure, and she has significant trouble in her relationships with Harriet and Marty. Though Harriet does not consciously make an attempt to accept the notion that it is her right as a modern woman to choose a lifestyle that allows her the ability to criticize Janie's decisions or lifestyle, Janie experiences the highest degree of happiness. As a result, she is in continual competition with Harriet. Janie's speech is often indecisive due to her perplexity, and she does not regard herself as equal to Harriet, but is readily swayed by both her parents and peers. Rather, she perceives herself as a second-class citizen. Janie Wasserstein remarked on Janie's quiet in a recent interview, describing Harriet as a lady who "had it all" in terms of education, fortune, and power: "Janie is a character who has a problem with education, wealth, and power," she said.

The struggle of women in getting their existence is the main analysis in this article. The reality of life faced by 
two friends, Janie and Harriet, represents the struggle for existence. The education they have, the decision to take action, and the intelligence in thinking are the benchmarks that the struggle for the existence of women continues to fluctuate in the story. In simple terms, the researcher then summarizes these phenomena in three main concepts as a form of representation of the struggle for existence. Independence over own became the first effort in fighting for the rights of an elected woman. The authority in making decisions shows that women's voices are important in the effort to gain existence. And the last one is related to the same treatment as human beings regardless of gender, male or female.

\subsection{Independency over itself}

Through her parent-daughter relationship, Janie's inability to establish her will be observed rather plainly. Her parents (Tasha and Simon) showed up unannounced at Janie's apartment to celebrate her arrival to New York. Tasha undermines Janie by criticizing her for not being in a meaningful relationship once they are together, rather than thanking her. When Tasha arrived to New York, she was both younger than Janie and already married, so she makes a reference to Janie's missing love life.

Harriet: "Hi ho, hi ho, it's off to work we go... I think I just got a job (they hug) $\mathrm{Hi}$, Janie!

Janie : "Hi, Harriet!"

Based on the data above, the researcher was identified the data as independency over women self, because the women namely Harriet don't need the permission to her parents and her family. The women wants make the rule of them as they want.

\subsection{The authority in making decisions}

Not all women dare to make a decision without a doubt. Marty's attitude in the story isn't it romantic provides an illustration of how women can express feelings, not only men who have authority over these feelings of love. The decision to say yes and no is sometimes not dared to be expressed by a woman because it is considered as something taboo. In contrast to what was done by Marty, he loudly gave his decision to say yes as a form of his authority over a decision. This can be seen in the following quote:

Marty: "Do you like me?"

Janie: "Yes, I do"

The data show that it was the authority in makin decisions. The reason is Janie as a speaker accepts the question or the offer from Marty. The, she doesn't need the suggestion from another people because she can determine about herself.

Janie: Hattie, do you think I should marry Marty?

Harriet: I never respected women who didn't learn to live alone and pay their own rent. Imagine spending your life pretending you aren't a person. To compromise on this would be antifeminist ... well, antihumanist ... well, just not impressive 


\section{sScience Htumanity Pournal}

\subsection{The same existence as a human}

The work leaves us with the pleasant feeling that these female characters have recognized the union between women as a useful tool in the search for their respective life options, thus finding in their female friends a tool with which to fight against traditional conventions that they tried to condition them. In Uncommon Women, Wasserstein manages to create an ideal microcosm to re \& ect the relationships between women that moves away from the common in time - going back years - and in space, in this exclusively feminine community. These circumstances give the impression that almost an experiment is being carried out on what a society made up of only women would be like - a topic that these girls also deal with in one of their many conversations and games - in which different types of relationships.

Harriet: "of course there's absolutely no reason why you should believe me"

Jannie: "you have an M.B.A from Harvard..."

From the data, the researcher got to identify from the same existence as a human. Harriet as a first women want the reason of her best friend that is Jannie, why Janie should believe her. It signifies that Harriet want to know why Janie should believe her.

\section{CONCLUSION}

The main focus of this article is on women's battle to gain the right to exist. The struggle for survival is represented by the reality of life experienced by two friends, Janie and Harriet. The education they have, the decision to take action, and the intelligence with which they think are the standards by which the story of women's struggle for survival continues to fluctuate. The researcher then puts these facts into three key themes as a representation of the struggle for survival in simple words. Independence over one's own became the first step in the campaign for a woman's right to vote. The power to make decisions demonstrates the importance of women's voices in the struggle for survival. Finally, regardless of gender, whether male or female, all human beings should be treated equally.

\section{REFERENCES}

Beauvoir, S. (2016). The second sex (Terjemahan Kehidupan Perempuan). (N. J. Tony Febrianto, Ed.). Yogyakarta: Narasi-Pustaka.

Cresswell. W Jhon \& Cresswll David J. (2018). Research design qualitative, quantitative and mixed methods approaches (fifth).

Dagun, S. M. (1990). Filsafat Eksistensialisme. Jakarta: Rineka Cipta.

Faruk, H. . (2003). Metodologi penelitian sastra (third). Yogyakarta: Hanindita.

Kindersley, D. (2019). The feminism (First; J. Andrews, V. HeyworthDunne, S. George, C. Meeus, C. Novis, \& R. Warren-Chadd, Eds.). New York: DK Publishing.

Klarer, M. (2004). An introduction to literary studies (Second; W. Buchgesellschaft, Ed.). New York: Rotledge.

Kuhon, F. (2020). Woman Representation in Poe's To Helen. IdeBahasa, 2(1), 59-68. Retrieved from 
https://jurnal.idebahasa.or.id/inde x.php/Idebahasa/article/view/33

Martin, V. (2001). Existentialism Philosophy: Kierkegaard, Sartre, Camus. Yogyakarta: Pustaka Pelajar.

Pruis, T. A., \& Janowsky, J. S. (2010). Assessment of Body Image in Younger and Older Women. General Psychology, 225-238. https://doi.org/10.1080/00221309 .2010 .484446

Sakinah, R. M. N. (2014). Citra Perempuan Dalam Novel The Holy Woman:Satu Kajian Feminis. Jurnal Balai Bahasa, 7, 73-84.

Showalter, E. (1997). The New Feminist Criticism. New York: Pantheon Books.

Simanungkalit, A. R., \& Putra, E. E. (2020). An Analysis Image of Women In Little Women Novel By "Louisa May Alcott." Jurnal Ellite, 03, 29-36.

Sinta , S., \& Ambalegin, A. (2020). The Struggle to Against Patriarchal Dominance in Romeo and Juliet Drama. IdeBahasa, 2(2), 141-154. https://doi.org/10.37296/idebaha sa.v2i2.47

Sudaryanto. (2015). metode dan aneka teknik analisis bahasa. Yogyakarta: Duta Wacana University.

Webster, M. (1828). Definition of function. Retrieved from https://www.merriamwebster.com/functioni 
pISSN 2774-1605 